\title{
A comparative analysis of selected national and regional investment initiatives that seek to achieve broadband expansion by deploying NGA networks
}

\author{
Fernando Beltrán \\ f.beltran@auckland.ac.nz \\ University of Auckland Business School \\ 12 Grafton Road - OGGB 472 \\ Auckland, New Zealand \\ Marlies Van der Wee \\ Marlies.VanderWee@UGent.be \\ IDLab \\ Department of Information Technology \\ Gent, Belgium \\ Sofie Verbrugge \\ sofie.verbrugge@ugent.be \\ IDLab \\ Department of Information Technology \\ Gent, Belgium
}

\begin{abstract}
Expectations about higher economic growth and the ever increasing demand for higher bandwidth and more reliable networks are driving the worldwide deployment of NextGeneration Access (NGA) networks. The paths followed to achieve this goal markedly vary, however, across different countries. This paper offers a comparison of a handful of leading NGA deployments that rely on different investment models. We study the broadband national initiatives of New Zealand and Australia and a group of selected regional NGA deployments in Europe.
\end{abstract}

While New Zealand's approach partially relies on a Public-Private Partnership model of investment, Australia's NBN is a wholly government-funded initiative and the European local initiatives in Sweden, Spain, the Netherlands and Portugal use a range of mixed models of 
investment. With these cases we aim to cover a large range of the spectrum of public and private modes of participation in infrastructure deployment.

We have developed a common technology-policy-market framework that allows for a clear mapping of the incentives, goals and actions of those involved in network deployment. By using the framework we investigate the links between the choice of investment model, including the level of public and private involvement, and other factors that may contribute to the success (or not) of each NGA deployment. Our main interest is in the identification of the drivers for investment in the cases studied as well as the description of main risk factors in each

case. By applying this framework to those selected deployment cases, while taking account of geographical characteristics and market structures, this work draws relevant conclusions about the impact of investment decisions on performance criteria such as coverage and uptake.

Keywords - Next-Generation Access Networks, Fibre-to-the-Premises, Public investment in Broadband, Public-Private Partnership, New Zealand, Australia, Europe

\section{Introduction}

Current trends in increasing demand for faster and more reliable broadband (BB) connections stimulate the deployment of Next-Generation Access (NGA) networks. However, deploying new infrastructure, especially Fibre-to-the-Premises (FTTP), requires significant levels of investment. Different economic investment models are currently being used worldwide to steer the deployments, ranging from no government intervention (fully private deployment), to a collaboration of private companies and public actors in a Public-Private Partnership (PPP), to public procurement or even fully government-driven and publicly-operated rollout. Furthermore, variants in scale of deployment can be identified: small rural town initiatives, regional solutions or nationwide projects. 
The nationwide PPP Ultra-Fast Broadband (UFB) network initiated by the government of New Zealand and the fully government-owned and funded Australian National Broadband Network (NBN) contrast sharply with the European local initiatives, which use mixed models of investment and are subject to constraints imposed on public money spending. Whereas the public partners (governments and local authorities) focus on increasing broadband coverage and stimulating the broadband ecosystem, private partners seek to establish a successful business case to the satisfaction of their shareholders. However a common aspect of the mixed deployment types is the alignment of goals by both public and private parties.

The cases identified in this paper not only cover different sizes in the scale of deployment but insightfully cover the spectrum of public and private modes of participation in infrastructure deployment. With the latter in mind, we aim to reveal the relationship between indicators of goal achievement and the characteristics of the investment vehicles. For example, qualitatively finding and assessing a relationship between the estimated amounts of risk shifted onto a private partner and the speed of deployment. Thus, the paper defines a common framework for effective comparison of the above-mentioned country and regional cases.

Inspired by (Melody, 2013) a Technology-Policy-Market interaction framework ${ }^{1}$ is proposed that allows for a clear mapping of the incentives, goals and actions of the different players in the field. Looking on the investment model used from a multi-domain perspective (technology, policy and the market) broadens our view and allows us to reach richer conclusions. This framework is applied to the following NGA deployment cases: New Zealand's UFB, the publicly-owned dark fibre infrastructure provider Stokab in Stockholm (Sweden), the fully government-funded NBN project in Australia, a PPP under the Market Economy Investors

\footnotetext{
${ }^{1}$ Melody, W.H., "Open standards: A shrinking public space in the future network economy?"
} 
Principle in Amsterdam (the Netherlands), a PPP initiated by the community in Catalonia, Spain, and a private initiative undertaken by the different providers, mainly the incumbent, in Portugal. These cases were chosen because they represent different types of investment mechanisms and so they cover the range of investment models of interest.

The goal of this paper is to investigate, on a case-to-case basis, the links between the choice of investment model, including the level of public and private involvement, and several factors that speak about the success of a NGA deployment. Then the paper identifies the drivers for investment in each case and the investment mechanism and looks into indicators relating to the main goals of the infrastructure deployment such as coverage and speed of deployment. As an important factor in the creation of incentives for private investment the paper also identifies the risk types shared between the partners across cases, whenever a partnership is the preferred vehicle for deployment. Placed on a straight segment with one end representing full government stewardship of a next-generation broadband access deployment and the other end representing fully private investment, the cases studied in this paper would sufficiently and variedly cover the space in between. Besides, their low number does not allow for a statistical approach to identifying correlation between factors and the measurement of interest.

The paper unfolds as follows: after providing an introduction to PPPs and government intervention in broadband deployment, the technology, policy and market aspects are brought together in the interaction framework presented. Next, the UFB programme in New Zealand, the NBN in Australia, and regional initiatives in Europe are respectively described and analysed. Following comparison criteria are used to highlight the commonalities and differences in how those cases have performed thus far. Conclusions and recommendations are formulated as a closure to the paper. 


\section{PPPs and government intervention in BB deployment}

This section presents a definition of the mechanism that allows a government to enter a partnership to undertake an infrastructure construction project and an overview of the range of options a government may rely upon when private participation is needed or preferred. In addition it introduces concepts, key to the assessment of performance of those NGA deployments examined here.

Although acceptance of FTTP as the preferred type of NGA deployment is not universal, the political decisions that have favoured deploying fibre to the customer look forward to futureproof the access network with the most reliable and capable technology available today. Politics aside, when a type of greenfield NGA is to be deployed in urban or sub-urban areas, technology and demand factors have shown that FTTP is preferred ${ }^{2}$. As investment incentives for private operators to upgrade their networks to full fibre networks ${ }^{3}$ have been absent, some governments have tried alternative financial initiatives. These initiatives have included both private and public investment (financing structure), as well as different forms of "authority aid", mainly in the form of laws or regulations. In this paper, we will mainly focus on the choice for and impact of the financing structure. Where deemed useful and to make the analysis relevant to policy makers, the paper also links the financial aspects to relevant regulatory decisions.

\footnotetext{
${ }^{2}$ Van der Wee, M. et al., Identifying and quantifying the indirect benefits of broadband networks for egovernment and e-business: A bottom-up approach.

${ }^{3}$ With full fibre networks, we refer to Fibre-to-the-Premises (FTTP), also referred to as Fibre-to-the-Home (FTTH). We argue for this type of networks over upgrades on copper (DSL) or coaxial cable (DOCSIS) networks, as these upgrades gradually bring fibre closer to the home, but still leave a last part of legacy infrastructure.
} 


\section{Forms of public and private participation in infrastructure project}

Figure 1 gives an overview of the five main financing structures that can be identified for large projects (not limited to telecommunication networks deployments). They range from $100 \%$ public investment to $100 \%$ private investment:

- In the complete government production and delivery, a public institution is responsible for the planning, deployment and maintenance of the project.

- When a public party invests the funds, but outsources the execution (and possible operations or maintenance) of the project to private partners, the investments mechanism is referred to as public procurement.

- A Public-Private Partnership (PPP) is characterized by both public and private investment, and hence, both public and private risk. This investment mechanism will be described in more detail further below.

- The fourth mechanism is a concession, frequently also referred to as a tender. In this case, the public party grants a private partner the rights to deploy and operate an infrastructure (or to execute and maintain a project). The private partner relies on revenues from the project's users, to recoup its investment. In this case, the private investment (and risk) is higher than in the case of a PPP.

- Full Private Investment is the final financing structure, and involves no public investment. 
Depending on the level of government involvement, different legal frameworks allow or forbid some of these investment mechanisms. In general, European policy holds that government intervention should only be allowed in cases where the market is not delivering the right quality and/or quantity. Lemstra and Groenewegen ${ }^{5}$ (2009) argue that governments should only intervene in case of a market failure, where it has been proven that the private market players have tried to correct the failure without any result. In this situation, the authorities can either use competition law to correct the abuse of market power, or set specific regulation on standards (quality of service) or impose price corrections through the use of taxes and subsidies.

Here, it should be noted that the European regulation on public involvements is specified in specific terms, and hence significantly different from other parts in the world. More precisely, we refer to the distinction between white, grey and black areas (European Commission, 2009); in principle, only in white areas is public subsidy in network allowed. As an exception, there are two scenarios in which public investment is not regarded as State Aid in accordance with the Case-law of the European Communities (“ECJ"):

- If the part of the investment that falls under the responsibility of the State can be used (in)directly by an undertaking in circumstances which correspond to normal market conditions, and,

\footnotetext{
${ }^{4}$ Adapted from OECD, "Public-Private Partnerships, in pursuit of risk sharing and value for money."

${ }^{5}$ Lemstra, W. \& J. P. M. Groenewegen, "Markets and public values - The potential effects of Private Equity Leveraged Buyouts on the safeguarding of public values in the telecommunications sector".
} 
- If a Member State considers the provision of broadband as a service of general economic interest, known as a service of general economic interest (SGEI) as qualified by the Altmark $^{6}$ criteria.

\section{Defining PPPs in the context of broadband expansion}

A PPP finds the middle point between public and private investment, and is defined as a contract between an authority (e.g. the national government or a municipality) and one or more private partners $^{7}$. By including both public and private money, the alignment of objectives can be achieved: that is, the service-delivery objective of the public parties along with the profitmaximization of the private parties $^{8}$, making the agreement mutually beneficial and economical $^{9}$. Another approach towards PPPs is seeing it as lying between the government and the market ${ }^{10}$, with the government representing centralized control of transactions and the market representing decentralized control.

One key aspect that differentiates PPPs from traditional procurement models is the fact that the agreement involves a risk-transfer mechanism; i.e. the private partners in a PPP must bear an agreed share of the (financial) risk, and as such are incentivized to deliver the product as

\footnotetext{
${ }^{6}$ The four conditions to meet in accordance with the Altmark criteria, as defined to in Article 86(2) of the Treaty of the European Community, are:

a) the beneficiary of a State funding mechanism must be formally entrusted with the provision and discharge of a SGEI;

b) the parameters for calculating the compensation must be established beforehand to avoid an economic advantage over competing undertakings;

c) the compensation cannot exceed what is necessary to cover all or part of the costs, taking into account the relevant receipts and a reasonable profit for discharging those obligations; and

d) the level of compensation granted must be determined on the basis of an analysis of the costs which a typical undertaking, well run, would have incurred in discharging those obligations, taking into account the relevant receipts and a reasonable profit.

${ }^{7}$ Ibid., 3.

${ }^{8}$ Fourie, F. and Burger, P., "An economic analysis and assessment of public-private partnerships (PPPs).”

9 Tylee, D., "ISCR Conference. A participant's perspective"

${ }^{10}$ Howell, B., "Meditating on Market Mechanisms."
} 
efficiently as possible. Thus PPPs are expected to deliver higher value-for-money by achieving the same goals as public procurement models, but at lower cost.

On the other hand, the involvement of public money is also key and provides the main differentiator to privatised projects. Public money ensures that government can impose their coverage targets and can provide a type of "subsidy" to ensure the economic viability of the entire project.

The OECD ${ }^{11}$ states that a well-established broadband deployment PPP must balance out four factors: 1. connectivity (in terms of universal service), 2. competition (by requiring enough private risk), 3. innovation (as the deployment of a new network generates opportunities on services and applications level) and 4. social benefit (benefit for other sectors of society). To ensure this, four elements should be included in the mechanism: the clear and long-term relationship between public and private partners, private equity as part of the funding, main objectives defined by the public actor, while implementation decisions left to the private one(s), and clear sharing of risk ${ }^{12}$.

\section{Assessing the success of deployments}

The most straightforward way to evaluate the success of a project is to verify to what extent its goals and targets have been reached upon completion. Even in cases where the deployment has not been finished yet, if information that monitors the construction pace is available, measurements of the quality of progress can be obtained. In all cases, the project goals, partial or whole, can be assessed.

\footnotetext{
${ }^{11}$ OECD, "The role of communication infrastructure investment in economic recovery."

${ }^{12}$ Falch, M., \& Henten, A. "Public private partnerships as a tool for stimulating investments in broadband."
} 
Where government participation is present, the drivers for investment are grounded on expectations of social return and economic benefit in the medium-term. Stakeholders in the deployment of an NGA network want to see construction deadlines met and targeted households reached. We are therefore relying on "coverage" (target and actual) as one indicator of the degree of success in meeting the goals.

It has also been recognised that private investment would not be able to provide a high-speed infrastructure before a desired point in time. In particular, due to the uncertain nature of NGA returns, the increasing demand for broadband services, and government goals for the reduction of the digital divide ${ }^{13}$ several regional European governments have invested in deployment of NGAs. Timing becomes then a pressing factor as government need to deliver on their broadband plans. In our assessment such need is represented on the speed of deployment (relative to targets) as another indicator included in our analysis.

A third aspect in the assessment is the level of risk involved in the deployment of an NGA. When the vehicle to expand broadband is a PPP one defining characteristic of the agreement is risk-sharing and the type and amount of risk transferred to the private partner shape the contractual relationship. Risk transfer is inherently linked to PPPs as part of the investment risk that should be borne by the private party. Beltrán ${ }^{14}$ argues that "it is the degree of risk transfer from the government onto the private party that determines the real nature of the contractual relationship between them".

Lacking accurate data about the financials of the cases analysed here, our approach is the identification, not the calculation, of the risk type involved in each of the investment

\footnotetext{
${ }^{13}$ Nucciarelli, A., Sadowski, B. and Achard, P. "Emerging models of public-private interplay for European broadband access: evidence from the Netherlands and Italy."

${ }^{14}$ Beltrán, F., "Effectiveness and Efficiency in the Build-Up of High-Speed Broadband Platforms in Australia and New Zealand."
} 
mechanisms used by the broadband initiatives. We use a categorisation of risk advocated by $\mathrm{OECD}^{15}$, which first divides risk between commercial risk, on one hand, and legal and political risk, on the other. In turn, commercial risk is further split into demand and supply risks. The former refers mainly to changes on the consumer side such as uptake and use of broadband services, as well as other commercial offers of substitute and complementary services, and financial risks affecting demand. The latter, intimately linked to the "ability of the private partner to deliver" ${ }^{\prime 16}$ and is divided into of construction risk - risks mainly associated with the availability and costs of inputs - and operation risk. In our descriptive assessment, we address the components of commercial risks.

\section{Technology - Policy-Market interaction framework}

Although the development of new products and services is facilitated by technology, they only make it into the market when demand for them has built up. Similarly, if market dynamics do not provide enough incentives for operators to, for instance, adopt new technologies and upgrade the networks, government intervention in the form of acts, laws or regulation could be justified. Finally, markets don't develop or evolve independent from policy decisions or technological innovations.

As such, the studied fibre deployment cases should be investigated within a framework that uses these three domains: technology, policy and market. Following the research by Melody (2013), who identified the impact of technology through applications, the impact of markets through services and the impacts of policy through the regulations, this paper uses the interaction between technology, policy and the market to describe how decisions on the

\footnotetext{
${ }^{15}$ Originally presented in Fourie, F. and Burger, P. Ibid., 7.

${ }^{16}$ OECD, "Public-Private Partnerships: In Pursuit of Risk Sharing and Value for Money."
} 
financing structure of the new deployments impact their performance as measured by a variety of criteria both in New Zealand and European cases as displayed in Figure 2.

The technology pillar groups all innovations, both in network upgrades and applications and services development, not limited to the telecom sector only. Within the scope of FTTH networks, it includes the choice of network topology (Point-to-Point P2P or Point-toMultipoint P2MP), network architecture (Active Ethernet or Gigabit Passive Optical Network (GPON)), deployment method (aerial or buried), equipment innovations (e.g. on ONT or OLT side), etc.

Insert Figure 2 here

The policy pillar comprises all laws, guidelines, regulations and directives that impact the deployment of FTTH either directly or indirectly. They can be made on local, regional, national or international level. Examples include wholesale price regulation, competition law, Digital Agenda guidelines, etc.

The third and final pillar, the market, combines all commercial and strategic decisions, both by the end-user and by the industry players itself. Examples include the customer's decision to take up on a fibre connection, the retailers' service offers in terms of speeds and caps and the NGA platform's wholesale tariff structure.

Next we will link the Technology-Policy-Market interaction framework used for analysing the cases to both factors of characterization and indicators of performance to evaluate the success of PPP in the deployment of fibre access networks. By focusing on the decisions made by actors 
in the three different pillars of the framework, the effect of their decisions on the other pillars can be studied, and possible interaction identified. Applying the framework on the financial decisive phase of different FTTH initiatives across New Zealand and Europe, allows analysing both the drivers behind implementing a certain investment model, as well as the success of that model on the specific initiative.

\section{A nationwide public-private partnership in New Zealand}

New Zealand government committed NZD \$1.5 billion to a FTHH network aimed to reach $75 \%$ of households and businesses, an initiative known as the Ultra-Fast Broadband network ${ }^{17}$. The remainder is to be served mainly by the Rural Broadband Initiative, through investment in wireless connectivity and VDSL connections. Crown Fibre Holdings (CFH), a publicly-owned company, was created to manage the investment funds. In $2017 \mathrm{CFH}$ denomination was changed to Crown Infrastructure Partners (CIP) Limited, expanding CFH's initial purpose ${ }^{18}$. A tender process saw four private companies win shares in the total investment funds to deploy the UFB. Three of these four partners are known as Local Fibre Companies (LFCs) and will eventually own and operate the network on a wholesale-only basis. They are: NorthPower Fibre, UltraFast Fibre, and Enable Services. Chorus, the fourth and largest partner established from a demerger of Telecom New Zealand into a wholesale company owning the network (Chorus) and a retailer (Spark), is not a LFC but instead CIP invests directly in it in the form of non-voting equity and debt securities.

\footnotetext{
${ }^{17}$ Sadowski, B., Howell, B., \& Nucciarelli, A. "Structural Separation and the Role of Public-Private Partnerships in New Zealand's UFB Initiative."; Crown Fibre Holdings, "Ultra-Fast Broadband for New Zealanders."

${ }^{18}$ As read from https://www.crowninfrastructure.govt.nz, the redefined purpose includes "investigating and implementing commercial models, including those that will enable co-investment from the private sector or any other sector, to achieve the Government's objectives for the deployment of water and roading infrastructure to support a timely increase in housing supply".
} 
The PPP was structured in two different models: the "funds-recycling" model with the LFCs, and the "investment" model with Chorus. The contract with the LFCs is based on the recycling of capital in which CIP funds the fibre passing (the dark fibre, Layer 1 network deployed along the streets) and when a customer shows interest to subscribe to fibre services the LFC then funds the drop section (from the street to the customer's premises). A subscription-based retail commercial relation then starts between the customer and a retail service provider, which in turn pays for capacity to the LFC at wholesale prices. This income is then used by the LFC to buy a share in the UFB network (so far owned by CIP), gradually acquiring ownership of the entire network as services are deployed. CIP in turn can re-invest the regained funds in network deployments elsewhere. The government's UFB network initiative could be described as a 'reverse PPP', where the government initially owns the PPP entity, takes risk and provides seed capital to private-sector partners to build the network, and then eventually sells out to privatesector partners ${ }^{19}$.

The contract signed with Chorus is different in the sense that CIP invests directly in Chorus as a company, but Chorus bears the main risks of the uncertain demand uptake. In return for this government loan, Chorus has to comply with specific coverage and uptake goals, set on milestone dates. Regulatory risks manifested in the changes to the regulation of the copper network, which led to a major change in Chorus composition of ownership with government investment funds replacing foreign capital ${ }^{20}$. In addition, the government has retained the power to exert control of Chorus if the provider does not meet its targets ${ }^{21}$.

\footnotetext{
${ }^{19}$ Howell, B. and Sadowski, B. "Anatomy of a Public-Private Partnership: Hold-up and Regulatory Risk in an NGN PPP.”

${ }^{20}$ Ibid 14.

${ }^{21}$ Ibid.
} 


\section{Australia's National Broadband Network}

The National Broadband Network (NBN) in Australia was originally conceived by the Labor government in 2008 as it sought to control Telstra's domination of the last-mile infrastructure in the emerging market of fixed broadband, responsible for Australia's low rankings in the OECD charts on broadband uptake and pricing throughout the 2000s. What was proposed as a nation-wide, high-speed FTTP network with an initial estimate of AUD \$42 billion turned out to be grounds for a heavy political fight. In 2009 the government established NBN Co to build and manage the fibre deployment; as fibre was expected to be rolled out and copper decommissioned, NBN Co would eventually become the sole provider of wholesale services to retailers and other interested parties. NBN Co planned to offer speeds of up to $100 \mathrm{Mbps}$ in towns with populations larger than 1000, comprising 93\% of Australian premises, by 2021. In 2011 the cost of building the NBN was revised down to AUD $\$ 37$ billion and the purchase of Telstra's copper network for additional AUD \$11 billion was announced. The deal with Telstra would gradually shut down its copper infrastructure, moving almost 10 million customers to the NBN.

With mounting pressure from the opposition ever since Labor announced its investment in the NBN, the largest infrastructure project in Australia's history, the landscape radically changed when Labor lost the 2013 election to the Coalition, a political force gathering conservatives and liberal democrats. Overnight, the Coalition set itself to change the investment plan for NBN. The first two years of Coalition-run NBN were spent in redefining the character of the network in terms of the deployed access technology. From the original 93\%-covered FTTH network, in 2017 NBN coverage plan is a mix of the following technologies: 18\% of premises with FTTP, $25 \%$ on HFC, $18 \%$ served by Fibre to the Distribution point (like fibre to the 
basement of an apartment building), 33\% with FTTN $^{22}$, 3\% with fixed wireless technology and the remaining 3\% with satellite. Minimum connection uplink rate is $25 \mathrm{Mbps}$, such as in satellite, with speeds going up to 1 Gbps on FTTP.

NBN Co's access service encompasses several classes of services; among those are the bitstream services, traffic classes, telephony capability, multicast, service operation, administration and maintenance, and physical interconnection agreements. The network must provide wholesale access service to any retailer wanting to offer services to end user.

\section{The case of Stokab in Stockholm}

Driven by the incentive to increase the economic attractiveness of the region of Stockholm, the city decided to invest in a FTTP deployment. Stokab, founded in 1994, is a public company, $100 \%$ owned by the city of Stockholm, and was established to deploy a dark fibre access infrastructure to all businesses and households in the Stockholm region. The company was founded as a public infrastructure company (comparable to other public firms responsible for road, railway etc.); all the development, deployment and operations is in direct hands of the company, no outsourcing is done. As the deployment started before the EU State Aid regulation was established, its public involvement was not questioned.

In its initial phase, the network rollout was financed by publicly-backed loans. As a first goal, the network aimed at connecting mainly public and educational institutions, but was quickly expanded towards private businesses, which requested to be connected on the dark fibre circuits. Although being a public company, taxpayer's money was never used. Instead, the initial $€ 300$ million investment was based on loans backed by the city of Stockholm, while the customers' revenues provided the necessary funds for a later expansion of the network. Note

\footnotetext{
${ }^{22}$ FTTN corresponds to VDSL, but achieved bandwidth speeds depend on the area.
} 
that about $50 \%$ of Stokab's revenues flows from direct business customers ${ }^{23}$ (e.g. banks, schools, etc.). Stokab reached a breakeven point in 2001, and is now a profitable company, although the majority of their profits is still re-invested in maintenance and further expansion of the network.

As in the first years, the deployment was mainly focused on larger businesses and public buildings, the speed of deployments (in terms of buildings passed) was not very high. The rollout speeded up drastically when the focus shifted to connecting more residential users, in the beginning of the 2000s. In mid-2013, 90\% of households and $100 \%$ of businesses in Stockholm had access to the fibre network. The goal of creating ultrafast reliable connections to the highly knowledge-intensive region that would "meet future communications needs, stimulate competition, promote diversity, offer freedom of choice and minimise the need for excavation" 24 , has definitely been reached. Stockholm is now home to a number of successful international companies (e.g. Skype, Spotify and Transmode), all of which were attracted to the "most densely fibred city in Europe".

\section{Deployments in the Netherlands: the case of Amsterdam}

In the case of Amsterdam, the city wanted to explore the importance of high-speed connectivity to the economic well-being of the city, and launched a formal investigation into the best way to proceed. Based on the outcome of several studies with and without the collaboration of the national incumbent, KPN, and the local cable operator, UPC, the municipality decided to create a public-private partnership (PPP) to invest in a passive fibre infrastructure. This PPP, GNA (Glasvezelnet Amsterdam BV) was incorporated with three groups of investors - the municipality itself, the housing associations and the private sector- each investing $€ 6$ million

\footnotetext{
${ }^{23}$ Broberg, A., "Challenges for an open physical infrastructure provider."

${ }^{24}$ Stokab, "This is Stokab."
} 
in return for a one third stake in the company. Another $€ 12$ million in funding was provided as debt financing, bringing the total investment to $€ 30$ million. Although GNA was taken to court multiple times by the cable operators, the public investment was eventually allowed under the Market Economy Investor Principle:

- All shareholders should invest under the same conditions in a profitable business with an acceptable risk/reward ratio.

- The network should be operated using the 'open network' concept, meaning that the wholesale specifies that all service providers must be able to purchase transport capacity on non-discriminatory conditions.

This investment fund of $€ 30$ million was used to cover about 40,000 homes with fibre access, this process took about 2.5 years and finished in February 2009. Then, GNA announced to connect the remaining parts of the city $(420,000$ homes in total) by 2013 , and estimated an overall budget of $€ 300$ million to do so $^{25}$. Soon, however, the ownership structure in Amsterdam changed, as Reggefiber (a passive infrastructure provider set up by an investment company (Reggeborgh)), bought about $70 \%$ of the shares, in a partnership with KPN (the Dutch incumbent). This evolution made tracking the actual process of the initial project hard. Though the project evolved in a different way than it was initially started, it remains an interesting example of how a PPP can be set up, and proved an example of multiple other, smaller, regional initiatives.

In general, across the Netherlands, most of the early first Dutch FTTH initiatives were taken by municipalities. Later on FTTH deployment in the Netherlands was mainly driven by Reggefiber. Since 2014 the Dutch incumbent KPN acquired 100\% ownership of Reggefiber.

${ }^{25}$ FTTH Council. "2016 FTTH Case Studies Collection: The FTTH Case Study of Amsterdam Citynet." 


\section{A community network in Catalonia, Spain}

Guifi.net presents an example of a totally different way of collaboration between public and private parties, by implementing a crowdsourced network ${ }^{26}$. In 2004, the initiative started by a group of enthusiasts that wanted to create amateur networking infrastructure, in order to serve the more rural areas that were not on the strategic roadmap of the commercial operators. Because of its initial success the group founded the Guifi.net Foundation and professionalised the offer. Four types of stakeholders participate in the network deployment and operations ${ }^{27}$ :

- Volunteers, responsible for management of the project, as well as development and maintenance of the software tools for network operations;

- Professionals, who invest in the network in return for fair compensation, and/or use the network to offer services (i.e. service providers) in return for a fair payment for this network usage;

- Customers, who use the offered services for a fair fee; and,

- Public administrations, regulating the public goods, interactions between other stakeholders, etc.

The network governance model is based on the Common Pool Resources framework, which assumes that all partners involved agree to and follow up on the same standardized ruleset, yet ownership remains with the stakeholder that invested. A specific compensation framework is in place to ensure fair (cost-based) payment for invested effort in network deployment or operations $^{28}$.

\footnotetext{
${ }^{26}$ Guifi.net, "The economic project."

${ }^{27}$ Baig, R., Roca, R., Freitag, F., \& Navarro, L. "Guifi. net, a crowdsourced network infrastructure held in common."

${ }^{28}$ Baig, R., Dalmau, L., Roca, R., Navarro, L., Freitag, F., \& Sathiaseelan, A. "Making Community Networks economically sustainable, the guifi. net experience."
} 
Though the network originally started as a small initiative in some towns in Catalonia, many regions in Spain now enter in the Guifi.net foundation for the deployment of their network infrastructure. The founders devote the success of the community network to its three underlying key principles: open, free and neutral. The openness refers to the fact that everyone can gain insights on how the network is built and operated (e.g. all software tools are open source), the network is free because access is non-discriminatory, and neutral because any technological solution is welcomed in network extensions.

\section{Mainly private investment in Portugal}

Although most European FTTH initiatives are based on some form of PPP, exceptional examples of other financing structures can be found. The main example for a pure private investment is to be found in Portugal, where the national incumbent, Portugal Telecom (PT), started a GPON rollout to face the fierce competition by the cable operator which could offer more attractive video-based offers using its HFC network. At the end of 2011, PT had passed 1.6 million homes ${ }^{29}$, in comparison to Vodafone Portugal, who has currently covered more than 700,000 homes with FTTH, while aiming for the 1.5 million target by mid-2015 (Vodafone, 2014). They recently announced that their copper network would be replaced by fibre almost completely ( $93 \%$ of homes) by $2020^{30}$.

This decision to upgrade to FTTH was helped by the decision of the National Regulatory Authority ANACOM who adopted a segmented regulation after a market analysis in 2008. The decision determined that access to ducts and associated infrastructure (so-called market 4) should be an obligation for all infrastructures (DSL, DOCSIS cable and FTTH), but that a

\footnotetext{
${ }^{29}$ FTTH Council, "Portugal Telecom. Incumbent gains competitive advantage with FTTH."

${ }^{30}$ Alveirinho, J., "Portugal Telecom An All-Fiber Company In An All-Fiber Country."
} 
wholesale offer (bitstream access, market 5) should only regulated in non-competitive areas. In areas with sufficient competition (defined as areas where the percentage of passed homes by the main competitor - the cable operator $\mathrm{ZON}$ - is larger than $60 \%$ ), there is as such no Significant Market Power (SMP), and according to European guidelines, no need for access regulation $^{31}$. In most of these competitive regions, the combined market shares of ZON and PT currently exceeds $85 \%$.

The upgrade of Portugal Telecom's network started in 2007 and was a gradual process. First, the network was quickly upgraded to DSL and later the copper loop was shortened by Fibreto-the-Node installations, with the final step deploying fibre to the actual homes with the GPON technology. The choice for GPON was largely based on its capability for broadcasting, as many Portuguese homes have multiple TV-sets and thus require enough signals (the analogue TV signals could be carried over a third wavelength in the GPON system (RF overlay)). Although originally only open to Portugal Telecom's customers (see above, no enforced regulation), Portugal Telecom announced in 2016 that they would also launch a wholesale offer for other operators to use their FTTP network ${ }^{32}$.

Apart from the pure private GPON investment, Portugal Telecom also signed co-investment sharing agreements with Vodafone for easy and cost-efficient upgrading of the mobile network to LTE, providing Portugal Telecom with the opportunity of offering quadruple-play for competitive prices.

Finally, in other areas of Portugal (the mainly rural, non-competitive areas), the government opened public tenders for the deployment of a wholesale network that would cover $50 \%$ of the

\footnotetext{
${ }^{31}$ Anacom, "Mercados grossistas de acesso à infraestrutura de rede num local fixo e de acesso em banda larga (in Portuguese)."

32 Portugal Telecom, "PT moves forward with wholesale offer for fiber network."
} 
targeted population with a minimum download bandwidth of $40 \mathrm{Mbps}$. In these areas, Portugal Telecom deploys an open access network with a wholesale offer for passive access ${ }^{33}$.

\section{Comparison of deployments}

For all cases studied here Table 1 summarises the most important decisions as referred to each of the three aspects (pillars) considered by the framework. The chronology of the decisions is revealed by the bracketed numbers showing first on each table entry, with (1) indicating the oldest decision. Table 1 is complemented with Table 2, which assesses the extent to which the factors chosen as performance indicators have been met.

Table 2 displays in two parts: the upper section describes the aspects driving the deployment in each case, particularly what motivates governments to act, while the lower section displays data on construction targets. In addition Table 3 summarises the information used for estimating the speed of deployment, the measurement of comparison for which enough data is available.

Insert Table 1 here

Insert Table 2 here

${ }^{33}$ Ibid., 24. 
Having summarised the main aspects of the country and region cases above within the domains of the Technology-Policy-Market framework, we turn now to draw a comparative assessment across the groups of international deployments. We first use the data available about deployment and time to achieve it to provide a quantitative approach to the speed of deployment, before turning to a more qualitative comparative analysis based on the information on Tables 1 and 2.

An estimate of the speed of deployment is obtained by taking account of the number of fibre connections reported over a period of time. Although several issues may arise, calculating such gradient provides a comparator that allows observing a difference across deployments. The difficulties with this approach lie on selecting a meaningful time interval over which construction is advanced under somewhat normal conditions (for instance, in accordance to plans). Also, when disturbances have arisen that impeded the steady delivery of connections passed, the duration of such time interval should be long enough to offset or amortize their effects.

Table 3 displays the values of the number-of-connections-passed to total-time-of-deployment ratio as a proxy to the speed of deployment for selected periods of time in most cases discussed here. The table also adds a measurement of speed of deployment per 1,000 people to take account of the size of the population target for each deployment.

In spite of the differences in the overall size of each initiative, all deployments are urban as far as FTTP concerns. Nationwide deployments take longer and achieve comparatively higher deployment rates than their city counterparts. The Australian and Stokab cases are presented in two stages, with the split in each case corresponding to major policy changes either during construction or as a result of an expansion of the original plan, respectively, , as Table 3 shows. 
These figures alongside the New Zealand ones show how progress in initial build up stages is slower than progress at later times.

Insert Table 3 here

Returning to the summaries provided by Tables 1 and 2, New Zealand's UFB initiative sets $75 \%$ - upgraded to $85 \%$ with the addition of the second phase of the project in 2016 - as the targeted proportion of households with passing fibre; the coverage goal in NZ is similar to that found in Portugal but in local (city) initiatives the targets are much higher. Australia's plan relies on a mix of technologies that aim at $76 \%$ coverage using fibre (in different standards).

Coordination and scale issues cause a nationwide project face bigger hurdles as the geographic area to cover is much larger than in the citywide cases.

City governments can plan for and target almost all premises, especially in conditions where population density is rather high, 4,892 and 3,597 people per sq. $\mathrm{km}$ in Stockholm and Amsterdam, respectively ${ }^{34}$. An increase in population density leads in general to a decrease in network deployment $\operatorname{cost}^{35}$. In spite of its lower population density - 17 people per sq. $\mathrm{km}$, and also because of that, New Zealand did not commit to a higher target. Neither is the rural part of the country targeted by the Portuguese plan, at least not at the present stage. New Zealand's UFB original decision to only reach $75 \%$ of population was based on a cost-coverage tradeoff, one that a smaller scale deployment with less cost per home passed would not have to face. On the other hand, a governmental initiative would normally be expected to focus more on

\footnotetext{
${ }^{34}$ Wikipedia, "Population density of European cities."

${ }^{35}$ Van der Wee, M. et al., "Evaluation of the Techno-Economic Viability of Point-to-Point Dark Fiber Access Infrastructure in Europe."
} 
universal coverage, thereby making sure all households are offered the ability to connect. In the case of New Zealand, the Rural Broadband Initiative - a complementary deployment to UFB - targets this goal, albeit using less costly (VDSL and fixed-wireless) solutions.

Though the Australian case is clearly steered from the policy corner (as all major decisions in the NBN project are initiated and managed by the government, leaving not much space to the market component), this also presents its most important hurdle. The political disagreement between major political forces changed the deployment plans several times, leading to ambiguity. The original plan recognised the geographical hurdles and decided that $7 \%$ of households would not get fibre; the 2013 election brought in a new government, which had been acutely critical of the original proposed NBN's targets, resulting in a major revision of the project's targets and technologies of choice.

In terms of the speed of deployment, New Zealand's CIP reports show that deployment has consistently surpassed the established targets and, overall, the project is on track to be finished earlier. In spite of the controversial review of the price of unbundled copper lines by the Commerce Commission with expectations that such decision could impact the deployment in areas served by Chorus, reports indicate that no delays are now forecast.

In Amsterdam, the cable (DOCSIS) operator UPC took the municipality's investment plan to court, because it was said to distort a well-functioning market. Although granted in the end, these court processes delayed the entire project significantly, and as such had a massive impact on the termination dates. In Stockholm, the initial network deployment was not set at a target speed of deployment, but was rather adjusted to market demand. Now that the network is operational and mature, targets are being set to connect the remainder of the homes.

With the exception of Australia's NBN, the fibre deployments have proven effective when government was or has been involved. These cases show an on- or above-target speed of 
deployment, with a warning message about how regulatory uncertainties may have a delaying effect on the progress of the deployment. In the case of Portugal, targets are more than met, and before target date, but as private operators not always disclose their goals, it is difficult to draw robust conclusions here.

Evaluating the links between the investment mechanism, the initiative drivers and the risk transfers reveals a strong relationship between the social-benefit driver and the investment of public money. In Australia, New Zealand and Amsterdam, the drivers followed the results of reports denoting the importance of broadband to society ${ }^{36}$, and in the latter two cases a PPP with significant private risk (equal private/public risk in Amsterdam) was used as an investment vehicle. In Stockholm, the city reacted to a request from businesses to be connected on a very high-speed, technology-neutral network. The investment there was fully public (publiclybacked loans) but the deploying company, Stokab, was set up to achieve return on investment rather quickly. In Portugal the driver was set by the market (emerging competition), and hence, the reaction to invest was also fully private. In conclusion, a competition driver is followed by a market response, a demand driver can be answered by a market or a public response, and a societal driver influences policy, the pillar that then leads the initiative.

As per the choice for either a purely public or a PPP investment, the link to the driver is less clear. Here, a significant influence of regulation on the policy pillar can be identified. For example, in the case of Amsterdam, purely public investment was not allowed, whereas alignment of the investment and sharing of the risk was a necessary condition for public involvement. One can tentatively conclude that the driver is crucial for the choice of investment mechanism, but the magnitude of public involvement is largely defined by regulatory rules.

\footnotetext{
${ }^{36}$ Department of Broadband, "National Broadband Network: Regulatory reform for 21st Century broadband"; Amsterdam, "Beleidsissues ten aanzien van 'glas-naar-de-meterkast"” ; The New Zealand Institute, "Delivering on the broadband aspiration: a recommended pathway to fibre for New Zealand.”.
} 
How the network is actually deployed and services are offered (technological pillar) is also impacted by the market and the policy pillars, as the cases show. The Australian approach fully publicly supported "open access", which means any retailer can purchase wholesale service from NBN and start to provide broadband-supported services. It is also the case of publicly backed network deployments under PPP scheme, which obliges in all cases an open-access network to be deployed, albeit on different layers. In all three cases (Stockholm, Amsterdam and New Zealand), the company or companies deploying the network cannot offer services directly to residential end-customers, but lease access (on a dark fibre or bitstream layer) to service providers, who then trade with end-users. In Portugal, the situation is completely different: not only is Portugal Telecom operating as a service provider as well (no open access), it is also fully vertically integrated, not even having to unbundle its network.

Considering the topology deployed ( $\mathrm{P} 2 \mathrm{P}$ or $\mathrm{P} 2 \mathrm{MP})$, it is harder to draw conclusions about impacting factors from the policy or market side. In general, open access is easier to be offered on a P2P network (one dedicated fibre per end-user is available), and therefore public parties tend to support P2P deployment more. In New Zealand however, cost considerations changed this initial idea towards a GPON deployment with a limited percentage of P2P access that should be granted upon request.

Of course, this topology decision also impacts the amount of risk incurred, as deploying P2P is more expensive, but does not generate significantly higher revenues from most (residential) users. The latter allows us to claim a link is found between the deployment decision and the investment mechanism. On the other hand, P2P allows for easy dark fibre access, which was a crucial factor in the topology decision in Stockholm, as up to 50\% of Stokab's revenue comes from business customers (banks, media companies, etc.), who lease dark fibre directly (so bypassing service providers). 


\section{Conclusions and recommendations}

Although is it generally recognised that the next step in broadband networks is the evolution to NGA, with a strong preference for FTTP networks, the investment required to actually deploy these networks is regarded as too high by many current telecom operators. As the importance of fast and reliable broadband to society and economic growth has been proven, more and more public actors decide to step in by investing in NGA networks; the ensuing projects, either local, regional or national, face multiple constraints, from capped budgets to regulatory norms to international trading and investment agreements.

This paper provided an extensive descriptive analysis of 6 different NGA deployment cases worldwide and studied the investment mechanisms used in these cases, with a focus on PublicPrivate Partnerships, by investigating the technology, policy and market interactions, and evaluates the success of the deployment in terms of deployment speed and coverage.

In general, our analysis showed the importance of the policy pillar in the deployments studied, be it as full investment, participation in a PPP or indirect aid in the form of regulatory holidays. The policy pillar furthermore showed to impact the technological pillar significantly, in obliging open access on a dark fibre (P2P topology) or bitstream (P2MP topology - GPON architecture) layer. The impact of the market pillar is limited in case of a public investment or PPP, but significant in the case of a private deployment, as there, the competitive threat provided a driver for investment. In all cases, the initiative lies with the policy or market pillar, and the technology pillar follows. In cases where the market takes the initiative, the technology pillar is less restricted than in policy-led cases.

The coverage targets are higher (in percentage of households) in smaller-scale deployments, as the range of cost per home passed is smaller and as such provides for easier planning. Although 
it could be expected that a government-driven deployment would target $100 \%$ of population (as to cancel out the digital divide), cost-coverage trade-offs have reduced this target, at least for FTTH coverage. In terms of speed of deployment, publicly-backed initiatives tend to achieve on or above targets.

Although the described cases here follow different approaches, Public-Private Partnerships are identified as a very promising option, implemented e.g. New-Zealand, Amsterdam and Stockholm. The main advantage of a PPP is probably that it combines the strengths and goals of public and private players. Public players reduce the risk for private players, and at the mean time make sure that the offers that are put on the market are fair and reasonable. Private players see a more reliable business case, but are still driven to employ their technical knowledge strengths to the maximum in order to minimize their own risk and ensuring sufficient return on investment.

Evaluating the success of NGA and FTTH deployments of course goes beyond assessing the coverage and speed of deployment. The work in this paper could be further extended towards including other evaluation characteristics, to fully investigate the efficiency and effectiveness of the cases. Effectiveness denotes whether the set goals are reached, and can span characteristics ranging from target coverage and speed of deployment, to uptake and envisaged return on investment. Efficiency measures the way the goals were reached, which includes budget evaluation and operational monitoring. 


\section{Acknowledgments}

The authors want to acknowledge received funding from the Agency for Innovation by Science and Technology in Flanders, Belgium, and the support of the FRD Fund of the University of Auckland.

\section{References}

Alveirinho, J. (2016). Portugal Telecom An All-Fiber Company In An All-Fiber Country.

DigiWorldSummit, November 2016, Montpellier, France.

Amsterdam (2002). Beleidsissues ten aanzien van 'glas-naar-de-meterkast'. Retrieved from CityNet Amsterdam. Available at: https://anzdoc.com/amsterdam-the-big-cherry-beleidsissues-tenaanzien-van-glas-.html

Anacom (2012). Mercados grossistas de acesso à infraestrutura de rede num local fixo e de acesso em banda larga (in Portuguese). Available at: http://www.anacom.pt/streaming/mercados4_5_ consulta_15022012.pdf?contentId=1116435\&field=ATTACHED_FILE

Anacom (2013). Report on Regulation, Supervision and Other Activities 2012 (page 24). Available at: http://www.anacom.pt/render.jsp?contentId=1184395\&languageId=1

Baig, R., Roca, R., Freitag, F., and Navarro, L. (2015). Guifi. net, a crowdsourced network infrastructure held in common. Computer Networks, 90, 150-165.

Baig, R., Dalmau, L., Roca, R., Navarro, L., Freitag, F., and Sathiaseelan, A. (2016, August). Making Community Networks economically sustainable, the guifi. net experience. In Proceedings of the 2016 workshop on Global Access to the Internet for All (pp. 31-36). ACM.

Beltrán, F. (2013). Fibre-to-the-home, high-speed and national broadband plans: Tales from Down Under. Telecommunications Policy. 38 (8-9), 715-729. 
Beltrán, F. (2013). Effectiveness and Efficiency in the Build-Up of High-Speed Broadband Platforms in Australia and New Zealand. Communications \& Strategies, (91).

Broberg, A. (2012). Challenges for an open physical infrastructure provider. ECOC Conference, Amsterdam, The Netherlands, September 2012.

Crown Fibre Holdings (2013). Ultra-Fast Broadband for New Zealanders. Website. Accessed 20-112013 from http://www.crownfibre.govt.nz/.

Department of Broadband, Communications and the Digital Economy (2009). National Broadband Network: Regulatory reform for 21st Century broadband, Commonwealth of Australia, Canberra, April 2009. http://www.dbcde.gov.au/_data/assets/pdf_file/0006/ 110013/NBN_Regulatory_Reform_for_the_21st_Century_Broadband_low_res_web.pdf European Commission (2009). Commission Communication 2009/C 235/04: Community Guidelines for the application of State aid rules in relation to rapid deployment of broadband networks.

European Commission (2011). State aid SA.30317 - Portugal - High-speed broadband in Portugal. Available at: http://ec.europa.eu/competition/state_aid/cases/236635/236635_1199063_71_2. pdf

Falch, M., and Henten, A. (2010). Public private partnerships as a tool for stimulating investments in broadband. Telecommunications Policy, 34(9), 496-504.

FTTH Council. 2016 FTTH Case Studies Collection: The FTTH Case Study of Amsterdam Citynet. Retrieved from: http://www.ftthcouncil.eu/documents/CaseStudies/CaseStudy_Collection_2016.pdf

FTTH Council (2011). Portugal Telecom. Incumbent gains competitive advantage with FTTH. FTTH Council Case study. Available at: http://www.ftthcouncil.eu/documents/CaseStudies/ PORTUGAL_TELECOM_Update1.pdf

Fourie, F. and Burger, P. (2000). An economic analysis and assessment of public-private partnerships (PPPs). The South African Journal of Economics, 68(4). 
Guifi.net (2017) The economic project. https://guifi.net/en/economic-project

Howell, B. and Sadowski, B. (2014). Anatomy of a Public-Private Partnership: Hold-up and Regulatory Risk in an NGN PPP. $20^{\text {th }}$ ITS Biennial Conference, Rio de Janeiro.

Howell, B. (2013). Meditating on Market Mechanisms. Competition and Regulation Times, November 2013.

Lemstra, W. and Groenewegen, J. P. M. (2009). Markets and public values - The potential effects of Private Equity Leveraged Buyouts on the safeguarding of public values in the telecommunications sector. Delft, The Netherlands: TUDelft.

Melody, W.H. (2013). Open standards: A shrinking public space in the future network economy? ITU Kaleidoscope: Building Sustainable Communities (K-2013).

Nucciarelli, A., Sadowski, B. and Achard, P. (2010). Emerging models of public-private interplay for European broadband access: evidence from the Netherlands and Italy. Telecommunications Policy, 34(9): 513-27.

OECD. (2008). Public-Private Partnerships, in pursuit of risk sharing and value for money. Available from: http://www.oecd.org/governance/budgeting/public-privatepartnershipsinpursuitofrisk sharingandvalueformoney.htm

OECD (2009). The role of communication infrastructure investment in economic recovery. Available from: http://www.oecd.org/internet/broadbandandtelecom/42799709.pdf

Portugal Telecom (2016). PT moves forward with wholesale offer for fiber network. Press release of March 15, 2016. https://www.telecom.pt/enus/media/noticias/Pages/2016/marco/pt_avanca_com_oferta_grossista_para_a_rede_fibra.aspx

Sadowski, B., Howell, B., and Nucciarelli, A. (2013). Structural Separation and the Role of PublicPrivate Partnerships in New Zealand's UFB Initiative. Communications \& Strategies, (91).

Stokab (2014). This is Stokab. Last accessed 2014-03-14 from http://www.stokab.se/In-english/ 
The New Zealand Institute (2008) Delivering on the broadband aspiration: a recommended pathway to fibre for New Zealand. Available at: http://nzinitiative.org.nz/site/nzbr/files/ Delivering_on_the_broadband_aspiration.pdf

Tylee, D. (2013). ISCR conference. A participant's perspective. Competition and Regulation Times, November 2013.

Van der Wee, M., Verbrugge, S., Sadowski, B., Driesse, M., and Pickavet, M. (2014). Identifying and quantifying the indirect benefits of broadband networks for e-government and e-business: A bottom-up approach. Telecommunications Policy, 39(3) 176 - 191.

Van der Wee, M. Verbrugge, S., Tahon, M., Colle, D. and Pickavet, M. (2014). Evaluation of the Techno-Economic Viability of Point-to-Point Dark Fiber Access Infrastructure in Europe. Journal of Optical Communication Networks 6 (3), 238-249.

Vodafone (2014). News release: Vodafone wins award for its rollout of fibre in Europe. Available at http://www.vodafone.com/content/index/media/vodafone-group-releases/2014/award-fibrerollout.html

Wikipedia (2014). Population density of European cities. Available at http://en.wikipedia.org/wiki/List_of_European_Union_cities_proper_by_population_density 
Public investment

4 Complete

government

production and

delivery

Public

procurement

Public-Private

Partnership

Concession

Privatisation

Private investment

Figure 1: Overview of types of public private collaboration possibilities 


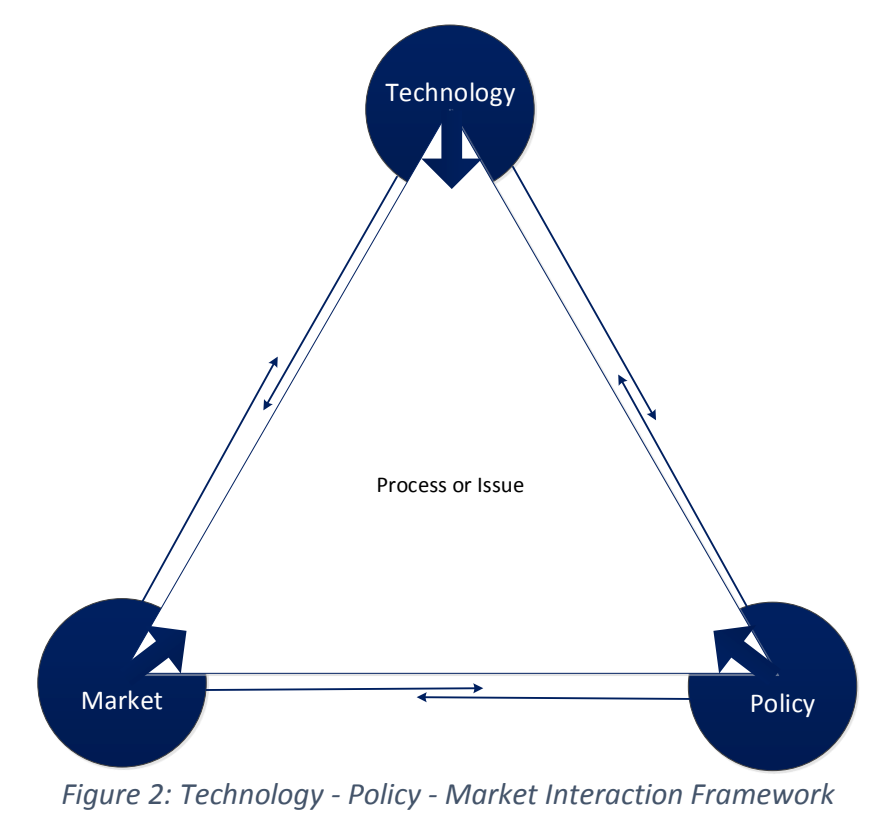

Table 1: Overview of the most important impacting decisions using the three-pillar framework on regional and country cases

\begin{tabular}{|c|c|c|c|c|c|c|}
\hline Decisions & New Zealand & Australia & $\begin{array}{l}\text { Stockholm, } \\
\text { Sweden }\end{array}$ & $\begin{array}{l}\text { Amsterdam, } \\
\text { the Netherlands }\end{array}$ & Catalonia, Spain & Portugal \\
\hline Policy pillar & $\begin{array}{l}\text { (1)Government } \\
\text { investment }\end{array}$ & $\begin{array}{l}\text { (1) Initiative by } \\
\text { government party } \\
\text { (6) Major changes when } \\
\text { coalition took power }\end{array}$ & $\begin{array}{l}\text { (2) Foundation of } \\
\text { Stokab }\end{array}$ & $\begin{array}{l}\text { (1) Amsterdam City } \\
\text { investment under } \\
\text { market economy } \\
\text { investor principle }\end{array}$ & $\begin{array}{l}\text { (2) Initiatives from } \\
\text { local citizens } \\
\text { (3) Common Pool } \\
\text { Resources } \\
\text { framework }\end{array}$ & $\begin{array}{l}\text { (2) No unbundling } \\
\text { obligation }\end{array}$ \\
\hline Market pillar & $\begin{array}{l}\text { (5) Demerger of } \\
\text { Telecom } \\
\text { (2) Wholesale only }\end{array}$ & $\begin{array}{l}\text { (2) No competition on } \\
\text { infrastructure } \\
\text { (3) Wholesale only } \\
\text { (4) Buy-out of Telstra's } \\
\text { network }\end{array}$ & $\begin{array}{l}\text { (1) Demand from } \\
\text { business users } \\
\text { (3) Dark fibre only }\end{array}$ & $\begin{array}{l}\text { (2) Taken to court by } \\
\text { UPC } \\
\text { (3) Dark fibre only }\end{array}$ & $\begin{array}{l}\text { (1) Community } \\
\text { initiative, } \\
\text { competition on } \\
\text { higher layers }\end{array}$ & $\begin{array}{l}\text { (1a) Competitive } \\
\text { threat from cable } \\
\text { (1b) Vertical } \\
\text { integration, later } \\
\text { wholesale offer }\end{array}$ \\
\hline
\end{tabular}




\begin{tabular}{|c|c|c|c|c|c|c|}
\hline $\begin{array}{l}\text { Technology } \\
\text { pillar }\end{array}$ & $\begin{array}{l}\text { (3) GPON } \\
\text { deployment } \\
\text { (4) Bitstream access }\end{array}$ & $\begin{array}{l}\text { (5) } 93 \% \text { FTTP } \\
\text { (6) Mix of } \\
18 \% \text { FTTP } \\
25 \% \text { HFC, } \\
18 \% \text { FDp } 33 \% \text { FTTN, } \\
3 \% \text { fixed wireless, } \\
3 \% \text { satellite. }\end{array}$ & $\begin{array}{l}\text { (4) Technology-neutral } \\
\text { passive infrastructure }\end{array}$ & $\begin{array}{l}\text { (4) Technology-neutral } \\
\text { passive infrastructure }\end{array}$ & $\begin{array}{l}\text { (4) Technology mix, } \\
\text { depending on the } \\
\text { area }\end{array}$ & $\begin{array}{l}\text { (3) Gradual upgrade } \\
\text { of DSL network; no } \\
\text { new network } \\
\text { deployment }\end{array}$ \\
\hline $\begin{array}{l}\text { Type of public- } \\
\text { private } \\
\text { collaboration }\end{array}$ & $\begin{array}{l}\text { Public-private } \\
\text { partnership/Conces } \\
\text { sion }\end{array}$ & $\begin{array}{l}\text { Public procurement / } \\
\text { Complete government } \\
\text { delivery (operation) } \\
\text { government-owned } \\
\text { company }\end{array}$ & $\begin{array}{l}\text { Complete government } \\
\text { production and } \\
\text { delivery }\end{array}$ & $\begin{array}{l}\text { Public-private } \\
\text { partnership }\end{array}$ & $\begin{array}{l}\text { Public-private } \\
\text { partnership }\end{array}$ & Private investment \\
\hline
\end{tabular}

Table 2: Factors characterising and indicators comparing the different case studies

\begin{tabular}{|c|c|c|c|c|c|c|}
\hline $\begin{array}{l}\text { Factors and } \\
\text { indicators }\end{array}$ & New Zealand & Australia & $\begin{array}{l}\text { Stockholm, } \\
\text { Sweden }\end{array}$ & $\begin{array}{l}\text { Amsterdam, } \\
\text { the Netherlands }\end{array}$ & Catalonia, Spain & Portugal \\
\hline $\begin{array}{l}\text { Initiative } \\
\text { drivers }\end{array}$ & $\begin{array}{l}\text { Societal value of } \\
\text { BB } \\
\text { Political incentive }\end{array}$ & $\begin{array}{l}\text { Societal benefits } \\
\text { of BB } \\
\text { Expectations of } \\
\text { higher growth }\end{array}$ & $\begin{array}{l}\text { Economic } \\
\text { attractiveness of the } \\
\text { region (businesses) }\end{array}$ & $\begin{array}{l}\text { Value of broadband } \\
\text { for households }\end{array}$ & $\begin{array}{l}\text { Community and } \\
\text { local citizens }\end{array}$ & $\begin{array}{l}\text { PT's response to } \\
\text { increasing } \\
\text { competition from } \\
\text { the cable operator }\end{array}$ \\
\hline $\begin{array}{l}\text { Investment } \\
\text { mechanism }\end{array}$ & $\begin{array}{l}0 \% \text { interest loan/ } \\
\text { Public-Private } \\
\text { Partnership with } \\
\text { recycled shares }\end{array}$ & $\begin{array}{l}\text { Federal } \\
\text { government } \\
\text { ownership }\end{array}$ & $\begin{array}{l}\text { Public ownership } \\
\text { and deployment }\end{array}$ & $\begin{array}{l}\text { Public-Private } \\
\text { Partnership }\end{array}$ & $\begin{array}{ll}\text { Common Pool } \\
\text { Resources } & \\
\text { framework } & \\
\end{array}$ & $\begin{array}{l}\text { Private } \\
\text { investment, } \\
\text { ownership and } \\
\text { deployment }\end{array}$ \\
\hline Risk transfer & $\begin{array}{l}\text { Mixed model of risk } \\
\text { transfer }\end{array}$ & $\begin{array}{l}\text { NBN Co is sole } \\
\text { provider }\end{array}$ & & $\begin{array}{l}\text { Market Economy } \\
\text { Investor Principle }\end{array}$ & & \\
\hline
\end{tabular}




\begin{tabular}{|c|c|c|c|c|c|c|}
\hline $\begin{array}{l}\text { Supply-side } \\
\text { risk }\end{array}$ & $\begin{array}{l}\text { LFCs assume 'drop' } \\
\text { construction risk }\end{array}$ & No private risk & No private risk & $\begin{array}{l}\text { Parties take risk by } \\
\text { equal parts }\end{array}$ & $\begin{array}{lr}\text { Majority } & \text { risk } \\
\text { taken } & \text { by } \\
\text { localities } & \text { with } \\
\text { support from } & \text { fricipalities }\end{array}$ & $\begin{array}{l}\text { Private investor } \\
\text { takes } 100 \% \\
\text { demand risk }\end{array}$ \\
\hline $\begin{array}{l}\text { Demand-side } \\
\text { risk }\end{array}$ & $\begin{array}{l}\text { LFCs not exposed } \\
\text { to risk for the initial } \\
\text { deployment } \\
\text { (recycling funds } \\
\text { model) } \\
\text { Chorus risk reduced } \\
\text { by } 0 \% \text { interest loan } \\
\text { from government }\end{array}$ & $\begin{array}{l}\text { NBN Co takes } \\
100 \% \text { demand- } \\
\text { side risk }\end{array}$ & $\begin{array}{l}\text { Stokab takes } 100 \% \\
\text { demand-side risk }\end{array}$ & $\begin{array}{l}\text { Parties assume risk } \\
\text { by equal parts }\end{array}$ & & $\begin{array}{lr}\text { Private investor } \\
\text { takes } \quad 100 \% \\
\text { supply-side risk. }\end{array}$ \\
\hline $\begin{array}{l}\text { Coverage } \\
\text { (achieved) }\end{array}$ & $\begin{array}{l}75 \% \text { of target } \\
\text { households, } \\
100 \% \text { of priority } \\
\text { users } \\
\text { (Mid-2017) }\end{array}$ & $\begin{array}{l}\text { As of Oct } 2017 \\
3 \mathrm{M} \text { connected } \\
\text { out of } 6.2 \mathrm{M} \\
\text { ready to connect. }\end{array}$ & $\begin{array}{l}90 \% \text { of } \mathrm{HH}, 100 \% \\
\text { of businesses } \\
\text { (May 2013) }\end{array}$ & $\begin{array}{l}40,000 \mathrm{HH} \text { by } 2009 \\
\text { (first project) }\end{array}$ & $\begin{array}{lr}55,000 & \text { nodes } \\
\text { and } & \text { counting } \\
(2017) & \end{array}$ & $\begin{array}{l}2.2 \text { million } \mathrm{HH} \\
(60 \% \\
\text { population) } \\
\text { (Dec 2012) } \\
\text { (Anacom, 2013) }\end{array}$ \\
\hline $\begin{array}{l}\text { Coverage } \\
\text { (target) }\end{array}$ & $\begin{array}{l}1,340,000 \mathrm{HH}, \\
75 \% \text { of population } \\
\text { mainly urban }\end{array}$ & $\begin{array}{l}76 \% \text { of } \\
\text { households to be } \\
\text { connected with a } \\
\text { mix or } \\
\text { technologies }\end{array}$ & $\begin{array}{l}450,000 \mathrm{HH} \\
100 \% \text { of Stockholm } \\
\text { (dense) urban }\end{array}$ & $\begin{array}{l}\text { 420,000 HH } \\
\text { (dense) urban }\end{array}$ & $\begin{array}{lr}\text { No } & \text { specific } \\
\text { target, new } & \text { project proposals } \\
\text { are always } & \text { evaluated }\end{array}$ & $\begin{array}{l}\text { Broadband over } \\
\text { NGN to >50\% } \\
\text { population by } \\
2013 \text { (European } \\
\text { Commission, } \\
\text { 2011) }\end{array}$ \\
\hline
\end{tabular}


Table 3. Speed of deployment in selected country/region cases

\begin{tabular}{|c|c|c|c|c|}
\hline Country/Region & $\begin{array}{l}\text { Time } \\
\text { period }\end{array}$ & $\begin{array}{l}\text { Number of } \\
\text { connections }\end{array}$ & $\begin{array}{c}\text { Speed of } \\
\text { deployment }{ }^{(i)} \\
\text { (\# connections } \\
\text { passed per day) }\end{array}$ & $\begin{array}{c}\text { Speed of } \\
\text { deployment per } \\
1,000 \text { POP (ii) }\end{array}$ \\
\hline \multirow[t]{2}{*}{ New Zealand UFB } & $\begin{array}{l}\text { Jan-11 } \\
\text { Dec-12 }\end{array}$ & 131,000 & 272.9 & 0.058 \\
\hline & $\begin{array}{l}\text { Jun-14 } \\
\text { Dec-17 }\end{array}$ & 750,000 & 872.1 & 0.186 \\
\hline Australia NBN & $\begin{array}{l}\text { Jan-10 } \\
\text { Dec-13 }\end{array}$ & 207,000 & 215.6 & 0.009 \\
\hline All technologies & $\begin{array}{l}\text { Jan-14 } \\
\text { Mar-18 }\end{array}$ & $6,600,000$ & 6470.6 & 0.268 \\
\hline FTTP (only) & $\begin{array}{l}\text { Jan-14 } \\
\text { Mar-18 }\end{array}$ & $1,425,000$ & 1397.1 & 0.058 \\
\hline \multirow[t]{2}{*}{ Stokab } & $\begin{array}{l}\text { Jan-07 } \\
\text { Jun-09 }\end{array}$ & 95,000 & 158.3 & 0.167 \\
\hline & $\begin{array}{l}\text { Jul-09 } \\
\text { Dec-12 }\end{array}$ & 300,000 & 357.1 & 0.376 \\
\hline Amsterdam & $\begin{array}{l}\text { Nov-06 } \\
\text { Feb-09 }\end{array}$ & 43,000 & 71.7 & 0.094 \\
\hline Portugal & $\begin{array}{l}\text { Oct-15 } \\
\text { Sep-17 }\end{array}$ & $1,500,000$ & 3125.0 & 0.303 \\
\hline
\end{tabular}

(i) Work month is 20 days

(ii) Population is either country total or city total

(iii) Australia's NBN has been a mixed-technology project. Fibre deployment switched from 100\% FTTP to an assortment of FTTX in 2014. Sources: New Zealand CFH; Australia NBN Co; Fibre to the Home Council Europe; Stokab.se; PT Portugal. 